\title{
ANALISIS PENGARUH LIKUIDITAS, STRUKTUR AKTIVA, FREE CASH FLOW, DAN UKURAN PERUSAHAAN TERHADAP KEBIJAKAN UTANG (DER) PADA PT JASA MARGA Tbk PERIODE 2009-2018
}

\author{
Anita Kristina *) \\ Prihatiningsih **) \\ Ida Savitri Kusmargiani **)
}

\begin{abstract}
This research is based on the problems of the company PT Jasa Marga Tbk which has a problem with the performance of the company which is indicated by the DER of companie increased during the period 2009-2018. The purpose of this research is to analyze the influance of direction and significance of Liquidity, Asset Structure, Free Cash Flow and Company Size on Debt Policy (DER) in PT Jasa Marga Tbk for the period 2009-2018.

The population and sample in this study were PT Jasa Marga Tbk. The analysis model used in this study is a multiple linear regression model.

The results of the multiple linear regression analysis showed that (1) the influance of Liquidity (CR) on Debt Policy (DER) was positive and significant (2) the influance Asset Structure on Debt Policy (DER) was negative and not significant (3) the influance of Free Cash Flow on Debt Policy (DER) is positive and significant (4) the influance of Company Size on Debt Policy $(D E R)$ is positive and significant.
\end{abstract}

Keywords: Debt Policy (DER), Liquidity (CR), Asset Structure, Free Cash Flow and Company Size

*) Mahasiswa Skripsi Prodi Analis Keuangan Jurusan Akuntansi Politeknik Negeri Semarang

**) Dosen Jurusan Akuntansi Politeknik Negeri Semarang

\section{PENDAHULUAN}

\section{Latar Belakang Masalah}

Persaingan dunia usaha yang semakin tinggi mengharuskan perusahaan menghadapi banyak tantangan, salah satu tantangan yang harus dihadapi terkait masalah pendanaan. Secara umum terdapat dua bentuk sumber pendanaan perusahaan yaitu sumber pendanaan internal dan eksternal. Sumber dana internal perusahaan yaitu dana yang diperoleh sendiri dari dalam perusahaan dapat berupa laba ditahan dan depresiasi. Sedangkan sumber dana eksternal perusahaan yaitu dana yang diperoleh dari luar perusahaan dapat berasal dari kreditur berupa utang, pemilik dan pengambil bagian di dalam perusahaan berupa modal asing dan modal sendiri (Riyanto, 2001:209-214).

Menurut Brealey \& Marcus (2006:25) keputusan pendanaan mempunyai urutan berdasarkan pecking order theory adalah dana internal, utang, dan penerbitan saham. Sumber pendanaan sebuah perusahaan dapat dipenuhi melalui sumber dana internal yang berasal dari laba ditahan perusahaan dan sumber eksternal berasal dari para kreditur dan investor. Apabila 
sumber dana internal tidak tercukupi perusahaan dapat menggunakan dana eksternal melalui utang lebih dahulu dan hanya menerbitkan ekuitas sebagai pilihan terakhir.

Kebijakan utang merupakan suatu kebijakan yang memungkinkan untuk memperoleh dana yang efektif dibandingkan dengan menerbitkan saham baru. Penawaran saham biasanya dianggap sebagai suatu sinyal bahwa prospek perusahaan kurang cerah menurut penilaian manajemennya (Brigham \& Houston, 2011:185-186).

Sektor infrastruktur, utilities dan transportasi memiliki kontribusi yang cukup besar di dalam perekonomian Indonesia. Namun, berdasarkan artikel yang dimuat pada situs resmi www.neraca.co.id pengamat ekonomi LIPI Latief Adam menerangkan bahwa investasi yang dilakukan di sektor infrastruktur itu mayoritas bersifat jangka panjang sehingga perlu jaminan pemerintah. Oleh karena itu, investasi yang dilakukan pada sektor ini memiliki risiko yang tinggi. Tingginya risiko dan penuh ketidakpastian, sehingga sulit untuk perbankan melakukan investasi ke infrastruktur.

Pada periode tahun 2014-2018 Pemerintah sedang gencar-gencarnya melakukan pembangunan infrastruktur, dalam rangka mengejar pertumbuhan ekonomi negara, khususnya dalam percepatan pembangunan di bidang infrastruktur. Hal ini bertujuan untuk menunjang kegiatan perekonomian Nasional, sebagai upaya mempersatukan bangsa serta untuk menekan ketimpangan daerah (Ray Jordan- detik finance, sabtu 7 April 2018). Maka dari itu, pemerintah mendorong Badan Usaha Milik Negara (BUMN) untuk melakukan kreativitas dalam mengelola asetnya. PT Jasa Marga (Persero) Tbk sebagai BUMN yang bergerak di subsektor jalan tol, bandara, pelabuhan dan sejenisnya yang secara konsisten melakukan inovasi strategi pendanaan agar dapat meningkatkan kapasitas investasi.

Beberapa faktor yang dapat digunakan untuk menurunkan Debt to Equity Ratio pada PT Jasa Marga Tbk melalui faktor-faktor pengaruhnya yaitu Current Ratio, Struktur Aktiva, Free Cash Flow dan Ukuran Perusahaan. Faktor pengaruh pertama adalah tingkat likuiditas. Tingkat likuiditas suatu perusahaan dapat diukur dari Current Ratio (CR). Berdasarkan research gap hasil penelitian Sari \& Prasetiono (2015) yang menyatakan bahwa likuiditas berpengaruh negatif signifikan terhadap leverage (DER), namun bertentangan dengan hasil penelitian Sabir \& Malik (2012) yang menyatakan dalam penelitiannya bahwa likuiditas berpengaruh positif signifikan terhadap Debt to Equity Ratio.

Faktor pengaruh kedua adalah Struktur Aktiva. Berdasarkan research gap hasil penelitian Hardiningsih dan Oktaviani (2012) yang menyatakan bahwa struktur aktiva berpengaruh positif signifikan terhadap Debt to Equity Ratio, namun bertentangan dengan hasil 
penelitian Deviani \& Sudjarni (2018) yang menyatakan dalam penelitiannya bahwa struktur aktiva berpengaruh negatif tidak signifikan.

Faktor pengaruh ketiga adalah Free Cash Flow (FCF). Berdasarkan research gap hasil penelitian Prathiwi \& Yadnya (2017) yang menyatakan bahwa Free Cash Flow berpengaruh positif signifikan terhadap Debt to Equity Ratio, namun bertentangan dengan hasil penelitian Narita (2012) yang menyatakan dalam penelitiannya bahwa Free Cash Flow berpengaruh negatif tidak signifikan.

Faktor pengaruh keempat adalah Ukuran Perusahaan. Berdasarkan research gap hasil penelitian Ifada dan Yunandriatna (2017) yang menyatakan bahwa ukuran perusahaan berpengaruh positif signifikan terhadap Debt to Equity Ratio, namun bertentangan dengan hasil penelitian Suryani dan Khafid (2015) yang menyatakan dalam penelitiannya bahwa ukuran perusahan berpengaruh negatif tidak signifikan terhadap Kebijakan Utang (DER).

\section{Rumusan Masalah dan Tujuan Penelitian}

Bagaimana arah pengaruh dan signifikansi Current Ratio (CR), Struktur Aktiva, Free Cash Flow dan Ukuran Perusahaan terhadap Kebijakan Utang (DER) pada PT Jasa Marga Tbk periode 2009-2018?

Untuk menganalisis arah pengaruh dan signifikansi Current Ratio (CR), Struktur Aktiva, Free Cash Flow dan Ukuran Perusahaan terhadap Kebijakan Utang (DER) pada PT Jasa Marga Tbk periode 2009-2018?

\section{KAJIAN TEORI}

\section{Teori Kebijakan Utang}

\section{Pecking Order Theory}

Menurut Breadly, Myers \& Marcus menjelaskan bahwa teori pecking order berbunyi sebagai berikut: (1) Perusahaan menyukai pendanaan internal, karena dana ini terkumpul tanpa mengirimkan sinyal sebaliknya yang dapat menurunkan harga saham, (2) Jika dana eksternal dibutuhkan, perusahaan menerbitkan utang lebih dahulu dan hanya menerbitkan ekuitas sebagai pilihan terakhir. Pecking order ini muncul karena penerbitan utang tidak terlalu diterjemahkan sebagai pertanda buruk oleh investor bila dibandingkan dengan penerbitan ekuitas.

\section{Trade Off Theory}

Menurut Brealey \& Marcus (2006:24) teori trade off ini memperkirakan bahwa rasio utang sasaran akan bervariasi dari satu perusahaan ke perusahaan lain. Lebih lanjut Breadly, 
Myers \& Marcus menjelaskan perusahaan dengan aset berwujud akan aman serta laba kena pajak melimpah yang harus dilindungi, sebaiknya memiliki rasio sasaran yang tinggi. Menurut Hanafi (2004:309) menyatakan bahwa semakin tinggi utang, maka akan semakin tinggi bunga yang harus dibayarkan.

\section{Agency Theory}

Menurut teori keagenan Brigham dan Houston (2006:26-30) menyatakan bahwa agency problem biasanya terjadi antara manajer, kreditur dan pemegang saham yang terjadi di dalam perusahaan, dimana manajer memiliki kurang dari 100\% saham perusahaan. Pengambilan keputusan pendanaan, pemegang saham lebih menginginkan pendanaan perusahaan dengan utang dibandingkan dengan menerbitkan saham baru, karena dengan diterbitkannya saham baru akan mengurangi hak suara mereka terhadap perusahaan. Sebaliknya, manajer tidak menginginkan pendanaan dengan utang, karena utang memiliki risiko yang tinggi. Begitu pula kreditur memiliki klaim laba perusahaan untuk pembayaran bunga dan pokok pinjaman serta aset perusahaan yang memadai untuk dijadikan jaminan, maka manajer harus bertindak adil dengan kreditur untuk memenuhi kewajibannya.

Upaya perusahaan dalam mengurangi agency cost biasanya menggunakan dana yang berasal dari utang. Peningkatan pendanaan dengan utang dapat menurunkan masalah keagenan yang ada dalam perusahaan, sehingga menurunkan kemungkinan pemborosan oleh manajemen (Wahidahwati, 2002) dalam (Indahningrum dan Handayani, 2009).

\section{Hubungan Antar Variabel}

\section{Hubungan Current Ratio (CR) terhadap Kebijakan Utang (DER)}

Likuiditas merupakan kemampuan perusahaan untuk memenuhi seluruh kewajiban lancar dengan aktiva lancarnya. Menurut Fahmi (2011:124) mengungkapkan bahwa memang bagi pihak manajer perusahaan yang memiiki Current Ratio yang tinggi dianggap baik, bahkan bagi kreditur dipandang perusahaan tersebut berada dalam keadaan yang kuat, yang berarti perusahaan semakin dapat mengembalikan utang lancarnya dengan aktiva lancar yang dimilikinya. Hal ini sesuai dengan pecking order theory, bahwa perusahaan akan lebih memilih pendanaan internal dan menekan utang. Melalui kemampuan likuiditasnya, perusahaan dapat meminimalisir tingkat risiko perusahaan oleh utang, dengan mengurangi tingkat utang atas kemampuannya membayar kewajiban jangka pendeknya.

\section{H1: CR berpengaruh negatif dan signifikan terhadap Kebijakan Utang (DER) Hubungan Struktur Aktiva terhadap Kebijakan Utang (DER)}


Aktiva merupakan salah satu jaminan yang bisa menyakinkan pihak lain untuk bisa memberikan pinjaman kepada perusahaan, sehingga perusahaan yang aktivanya sesuai dengan jaminan kredit akan lebih banyak menggunakan utang, karena kreditur akan selalu memberikan pinjaman apabila mempunyai jaminan (Brigham \& Houston, 2011:188). Menurut agency theory, yang membahas mengenai konflik kepentingan antara pemegang saham dengan kreditur menggambarkan, bahwa permasalahan overinvestment adalah lebih sedikit tingkat keseriusannya jika ada lebih banyak aset tetap yang dimiliki oleh perusahaan.

H2: Struktur aktiva berpengaruh positif dan signifikan terhadap Kebijakan Utang (DER)

\section{Hubungan Free Cash Flow terhadap Kebijakan Utang (DER)}

Menurut Ross et al (2000) dalam Trisnawati (2016) Free Cash Flow merupakan kas perusahaan yang dapat didistribusikan kepada kreditur atau pemegang saham yang tidak diperlukan untuk modal kerja atau investasi pada aset tetap. Menurut Jensen 1985 dalam Hanafi (2004:317) perusahaan dengan Free Cash Flow yang tinggi cenderung akan menimbulkan konflik keagenan, karena adanya kecenderungan penggunaan Free Cash Flow yang berlebihan oleh pihak manajer. Untuk mengendalikan Free Cash Flow yang berlebihan oleh manajer, maka penggunaan kebijakan utang akan dipilih sebagai sumber pendanaan perusahaan sehingga dapat mengurangi konflik keagenan dan agency cost of Free Cash Flow (Natasia dan Wahidahwati, 2015).

\section{H3: Free Cash Flow berpengaruh positif dan signifikan terhadap Kebijakan Utang} (DER)

\section{Hubungan Ukuran Perusahaan terhadap Kebijakan Utang (DER)}

Ukuran perusahaan adalah suatu skala yang dapat diklasifikasikan dalam besar kecilnya perusahaan dengan berbagai cara antara lain dengan total aktiva, log size, nilai pasar saham, dan stabilitas penjualan. Besar kecilnya ukuran suatu perusahaan akan berpengaruh terhadap utang perusahaan, yang didasarkan pada kenyataan bahwa semakin besar ukuran suatu perusahaan, maka kecenderungan menggunakan modal juga semakin besar. Selain itu, perusahaan besar dapat dengan mudah untuk mengakses ke pasar modal. Kemudahan untuk mengakses pasar modal berarti perusahaan memiliki fleksibilitas dan kemampuan untuk mendapatkan lebih banyak dana (Sujarweni et al, 2014).

H4: Ukuran Perusahaan berpengaruh positif dan signifikan terhadap Kebijakan Utang (DER) 


\section{METODE}

\section{Desain Penelitian}

Penelitian adalah sebah proses investigasi ilmiah terhadap sebuah masalah yang dilakukan secara terorganisir, sistematik, berdasarkan pada data yang terpercaya bersifat kritikal dan obyektif yang mempunyai tujuan menemukan jawaban atau pemecahan atas suatu atau beberapa masalah yang diteliti (Ferdinand, 2014:1). Desain penelitian yang digunakan dalam penelitian ini adalah penelitian kuantitatif terapan kausal.

\section{Jenis Data}

Penelitian ini menggunakan jenis data kuantitatif berupa data sekunder. Data sekunder dalam penelitian ini diperoleh dari laporan keuangan triwulan perusahaan PT Jasa Marga Tbk periode 2009-2018 yang dipublikasikan di www.idx.co.id. Sementara itu, data dalam penelitian ini menggunakan jenis data time series.

\section{Populasi dan Sampel}

Populasi dalam penelitian ini adalah keseluruhan obyek yang menjadi sasaran penelitian yaitu PT Jasa Marga Tbk. Sementara itu, teknik pengambilan sampel yang digunakan adalah teknik sampling jenuh. Sampling jenuh adalah teknik penentuan sampel bila seluruh anggota populasi digunakan sebagai sampel. Adapun sampel dalam penelitian ini adalah PT Jasa Marga Tbk.

\section{Operasionalisasi Variabel Penelitian}

Debt to Equity Ratio (DER)

DER merupakan rasio yang digunakan untuk mengukur besarnya proporsi utang terhadap modal (Hery, 2016:169).

$$
\text { DER }=\frac{\text { Total Utang }}{\text { Total Modal }}
$$

\section{Current Ratio (CR)}

Current Ratio merupakan rasio lancar yang digunakan untuk memenuhi utang jangka pendeknya dengan mengukur kemampuan perusahaan menggunakan aktiva lancarnya (Hanafi \& Halim, 2009:77).

$$
\mathrm{CR}=\frac{\text { Aktiva Lancar }}{\text { Utang Lancar }}
$$

\section{Struktur Aktiva}

Struktur aset berhubungan dengan jumlah kekayaan (aset) yang dapat dijadikan jaminan (Sujarweni et al, 2014). 


\section{STA $=\underline{\text { Aset Tetap }}$ \\ Total Aset}

\section{Free Cash Flow}

Free Cash Flow dihitung dengan menggunakan rumus dari Indahnigrum \& Handayani (2009) sebagai berikut:

$$
\mathrm{FCF}=\mathrm{Ln}(\mathrm{AKO}-\mathrm{PM}-\mathrm{NWC})
$$

Keterangan:

$\mathrm{AKO}=$ Aktivitas Kegiatan Operasi

$\mathrm{PM} \quad=$ Pengeluaran Modal

NWC = Net Working Capital (Aktiva Lancar - Utang Lancar)

\section{Ukuran Perusahaan}

Ukuran perusahaan dihitung dengan menggunakan rumus dari Masdupi (2005) dalam Trisnawati (2016) sebagai berikut:

Ukuran Perusahaan= Ln (Total Aset)

\section{HASIL DAN PEMBAHASAN}

\section{Statistik Deskriptif}

Tabel 1

Deskriptif Statistik

\begin{tabular}{|l|r|r|r|r|r|}
\hline & $\mathrm{N}$ & Minimum & Maximum & Mean & Std. Deviation \\
\hline DER & 40 & 1,06 & 3,53 & 1,8595 &, 69576 \\
CR & 40 &, 38 & 2,50 &, 9817 &, 47262 \\
STA & 40 &, 71 &, 92 &, 8145 &, 05729 \\
FCF & 40 & $-23,18$ & 23,38 & $-3,1085$ & 21,33843 \\
SIZE & 40 & 22,68 & 25,19 & 24,1558 &, 58300 \\
Valid N (listwise) & 40 & & & & \\
& & & & \\
\hline
\end{tabular}

Sumber: Data diolah 2019

\section{Uji Asumsi Klasik}

Uji asumsi klasik ini merupakan uji untuk melihat Best Linear Unbiased Estimator $(B L U E)$ dari model linier yang tidak bias atau memiliki ketepatan dan memberikan hasil terbaik untuk digunakan. Uji asumsi klasik ini terdiri dari uji linearitas, uji normalitas, uji multikolonieritas, uji heteroskedastisitas, dan uji autokorelasi.

\section{Uji Linearitas (Lagrange Multipler)}

Hasil Uji linearitas menunjukkan nilai $\mathrm{R}^{2}$ sebesar 0,000 dengan jumlah $\mathrm{n}$ observasi 40 , maka besarnya $\mathrm{c}^{2}$ hitung $=40 \times 0,000=0,000$. Nilai ini dibandingan dengan $\mathrm{c}^{2}$ tabel dengan $\mathrm{df}$ 
$=34$ dan tingkat signifikansi 0,05 didapat nilai $\mathrm{c}^{2}$ sebesar 2,38. Oleh karena nilai $\mathrm{c}^{2}$ hitung $(0,000)<c^{2}$ tabel $(2,38)$, maka dapat disimpulkan bahwa model yang benar adalah model linier.

\section{Uji Normalitas}

Berdasarkan hasil uji normalitas dari hasil uji statistik Non-Parametik KolmogorovSmirnov (K-S) menunjukan nilai yang signifikan yaitu sebesar 0,88 , dimana nilai tersebut lebih besar dari 0,05 . Hal ini menunjukkan bahwa data dalam penelitian ini terdistribusi secara normal.

\section{Uji Multikolinearitas}

Berdasarkan hasil uji multikolinearitas dapat diketahui bahwa variabel yang terdiri dari Current Ratio (CR), Struktur Aktiva, Free Cash Flow (FCF), dan Ukuran Perusahaan menunjukan bahwa tidak ada variabel independen yang memiliki nilai tolerance $<0,10$ dan VIF >10. Sehingga dapat disimpulkan bahwa model regresi linier tidak terjadi multikolinearitas.

\section{Uji Heteroskedastisitas}

Berdasarkan hasil uji heterokedastisitas menunjukkan, bahwa nilai probabilitas variabel CR sebesar 0,884, AST sebesar 0,291, FCF Sebesar 0,067 dan SIZE sebesar 0,983. Hal ini menunjukkan bahwa semua variabel independen memiliki nilai signifikan adalah lebih besar dari 0,05, maka dapat disimpulkan bahwa tidak terdapat masalah heterokedastisitas.

\section{Uji Autokorelasi}

Berdasarkan hasil uji autokorelasi dapat diketahui bahwa nilai test -0,02498 dengan probabilitas 0,262 , dimana nilai probabilitasnya lebih dari 0,05 yang berarti hipotesis nol diterima, sehingga dapat disimpulkan bahwa residual random atau tidak terjadi autokorelasi antar nilai residual.

\section{Uji Kelayakan Model}

Menurut Ghozali dan Ratmono (2013) uji kelayakan model sering disebut dengan Goodness of fit tujuannya untuk menguji ketepatan fungsi regresi sampel dalam menaksir nilai aktual. Secara statistik, setidaknya ini dapat diukur dari nilai uji F, uji t, dan uji koefisien determinasi $\left(\mathrm{R}^{2}\right)$.

\section{Uji F}

Berdasarkan hasil uji F menunjukkan bahwa Fhitung sebesar 109,316 lebih besar dari Ftabel 2,64. Nilai probabilitas F sebesar ( $p$-value) F sebesar 0,000 atau lebih kecil dari taraf signifikan 0,05 sehingga dapat disimpulkan bahwa secara simultan variabel Current Ratio 
(CR), Struktur Aktiva, Free Cash Flow (FCF) dan Ukuran Perusahaan berpengaruh signifikan terhadap Kebijakan Utang (DER).

\section{Hasil Uji t}

Tabel 2

Uji Hipotesis

\begin{tabular}{|c|c|c|c|c|c|c|}
\hline \multirow{2}{*}{\multicolumn{2}{|c|}{ Model }} & \multicolumn{2}{|c|}{$\begin{array}{c}\text { Unstandardized } \\
\text { Coefficients }\end{array}$} & \multirow{2}{*}{$\begin{array}{l}\begin{array}{l}\text { Standardized } \\
\text { Coefficients }\end{array} \\
\text { Beta } \\
\end{array}$} & \multirow[b]{2}{*}{$\mathrm{t}$} & \multirow[b]{2}{*}{ Sig. } \\
\hline & & B & Std. Error & & & \\
\hline \multirow[t]{5}{*}{1} & (Constant) & $-29,031$ & 2,772 & & $-10,473$ &, 000 \\
\hline & $\mathrm{CR}$ & ,382 & ,157 & 259 & 2,435 & , 020 \\
\hline & STA & $-1,463$ &, 885 &,- 120 & $-1,654$ & , 107 \\
\hline & FCF & ,005 & ,002 & , 163 & 2,552 & ,015 \\
\hline & SIZE & 1,313 & (093 & 1,100 & 14,129 & , 000 \\
\hline
\end{tabular}

a. Dependent Variable: DER

Sumber: Data diolah 2019

Berdasarkan hasil uji t menunjukkan, bahwa variabel (1) Current Ratio (CR) berpengaruh positif dan signifikan terhadap variabel Kebijakan Utang (DER), maka dari itu, Hipotesis 1 ditolak, (2) Struktur Aktiva berpengaruh negatif dan tidak signifikan terhadap variabel Kebijakan Utang (DER), maka dari itu, Hipotesis 2 ditolak, (3) Free Cash Flow (FCF) berpengaruh positif dan signifikan terhadap variabel Kebijakan Utang (DER), maka dari itu, Hipotesis 3 diterima, (4) Ukuran Perusahaan berpengaruh positif dan signifikan terhadap variabel Kebijakan Utang (DER), maka dari itu Hipotesis 4 diterima.

\section{Uji Koefisien Determinasi $\left(\mathbf{R}^{2}\right)$}

Berdasarkan hasil uji koefisien determinasi $\left(\mathrm{R}^{2}\right)$ dapat diketahui bahwa koefisien determinasi (adjusted $R$ square) sebesar 0,917 (91,7\%). Hal ini menunjukkan bahwa model penelitian yang diajukan memiliki kelayakan yang tinggi, karena variasi variabel-variabel independen yang digunakan yaitu variasi Current Ratio (CR), Struktur Aktiva, Free Cash Flow (FCF), dan Ukuran Perusahaan hanya mampu menjelaskan keberadaan variabel dependennya yaitu Kebijakan Utang (DER) sebesar 91,7\%, dimana sebesar 8,3\% dapat dijelaskan variasi variabel lain diluar model.

\section{Intreprestasi Model}

$\mathrm{DER}=-29,031+0,382 \mathrm{CR}-1,463 \mathrm{STA}+0,005 \mathrm{FCF}+1,313 \mathrm{SIZE}+e$

\section{Pembahasan Hasil Penelitian}

\section{Pengaruh Current Ratio (CR) terhadap Kebijakan Utang (DER)}

Berdasarkan pengujian hipotesis 1, menunjukkan bahwa variabel Current Ratio (CR) berpengaruh positif dan signifikan terhadap Kebijakan Utang (DER). Hal ini menunjukkan, 
bahwa naik turunnya Current Ratio (CR) perusahaan akan mempengaruhi besar kecilnya Kebijakan Utang (DER).

Nilai CR akan mempengaruhi kebijakan perusahaan dalam pengambilan keputusan pendanaan. Namun, perusahaan yang memiliki nilai CR rendah belum tentu akan dapat dibayarnya utang perusahaan yang sudah jatuh tempo, karena proporsi ataupun distribusi aktiva lancar yang tidak menguntungkan, misalnya jumlah persediaan yang relatif tinggi dibandingkan dengan taksiran tingkat penjualan yang akan datang atau adanya saldo piutang yang besar yang sulit untuk ditagih dll (Munawir, 2012:72). Selain itu, Current Ratio pada perusahaan Jasa Marga mengalami fluktuasi yang ditunjukkan dengan nilai rata-rata CR yang dimiliki sekitar 0,98. Hal ini menunjukkan bahwa perusahaan Jasa Marga Tbk mengalami inlikuid untuk membayar utang jangka pendek dari aktiva lancar yang dimiliki perusahaan. Maka dari itu, perusahaan Jasa Marga Tbk diperlukan pengelolaan aktiva lancar yang memadai agar mampu digunakan untuk menunjang kegiatan operasional ataupun membayar kewajiban jangka pendeknya.

Hal ini tidak sesuai dengan teori yang dibangun, bahwa dalam pecking oder theory menetapkan suatu keputusan pendanaan, dimana para manajer pertama kali akan memilih untuk menggunakan laba ditahan, utang dan penerbitan saham sebagai pilihan terakhir (Hanafi, 2004:313). Hal ini dikarenakan, apabila perusahaan lebih memilih pendanaan internal akan dapat menekan utang.

\section{Pengaruh Struktur Aktiva terhadap Kebijakan Utang (DER)}

Berdasarkan pengujian hipotesis 2, menunjukkan bahwa variabel Struktur Aktiva berpengaruh negatif dan tidak signifikan terhadap Kebijakan Utang (DER). Hal ini menunjukkan, bahwa naik turunnya Struktur Aktiva perusahaan tidak akan mempengaruhi besar kecilnya Kebijakan Utang (DER). Hal tersebut dapat disebabkan, karena perusahaan lebih cenderung untuk melakukan pengelolaan terhadap aset yang dimilikinya, agar mampu untuk menunjang aktivitas operasional perusahaan, sehingga mampu untuk menghasilkan return yang meningkat bagi perusahaan. Jika perusahaan mengambil keputusan utang, maka tidak terlalu mempertimbangkan Struktur Aktiva dalam pengambilan keputusan tersebut.

Hasil penelitian ini sesuai dengan penelitian yang dilakukan oleh Deviani dan Sudjarni (2018) menyatakan, bahwa arah negatif Struktur Aktiva memiliki arti semakin tinggi Struktur Aktiva, maka Debt to Equity Ratio akan semakin rendah. Selain itu, tidak signifikan menunjukkan bahwa dalam mengambil keputusan untuk DER, maka perusahaan tidak terlalu mempertimbangkan Struktur Aktiva dalam pengambilan keputusan pinjaman. 
Namun, tingginya Struktur Aktiva menunjukkan kekayaan yang dimiliki oleh perusahaan tersebut juga tinggi, sehingga dapat digunakan oleh perusahaan sebagai jaminan untuk mendapatkan utang. Namun, tidak berpengaruhnya Struktur Aktiva terhadap Kebijakan Utang (DER) pada PT Jasa Marga Tbk, yang berarti naik turunya Struktur Aktiva membuat perusahaan Jasa Marga Tbk akan tetap menggunakan utang untuk menunjang kegiatan operasional perusahaan, sebab dalam pengembangan proyek jalan tol perusahaan Jasa Marga akan membutuhkan dana segar tentunya yang berasal dari penerbitan utang obligasi, pinjaman utang dari bank dan penerbitan saham. Hal ini berarti, aktiva tetap yang dimiliki perusahaan dapat digunakan untuk kegiatan operasi perusahaan dalam menghasilkan laba, sehingga laba yang diperoleh perusahaan dapat digunakan untuk menambah investasinya kembali.

Hal ini tidak sesuai dengan teori yang dibangun, bahwa menurut agency theory yang membahas mengenai konflik kepentingan antara pemegang saham dengan kreditur menggambarkan, bahwa permasalahan overinvestment adalah lebih sedikit tingkat keseriusannya jika ada lebih banyak aset tetap yang dimiliki oleh perusahaan.

\section{Pengaruh Free Cash Flow terhadap Kebijakan Utang (DER)}

Berdasarkan pengujian hipotesis 3 menunjukkan bahwa variabel Free Cash Flow berpengaruh positif dan signifikan terhadap Kebijkan Utang (DER). Hal ini menunjukkan, bahwa Free Cash Flow akan mempengaruhi besar kecilnya Kebijakan Utang (DER). Maka dari itu, adanya peningkatan utang dapat mengurangi masalah keagenan karena dua alasan. Pertama, dengan meningkatnya utang, maka akan semakin kecil porsi saham yang harus dijual perusahaan, dikarenakan nilai saham yang beredar menjadi semakin kecil, sehingga akan mengurangi masalah keagenan yang timbul antara manajer dan pemegang saham. Kedua, semakin besar utang perusahaan, maka semakin kecil dana menganggur yang dapat dipakai manajer untuk pengeluaran-pengeluaran yang kurang perlu.

Hal ini sesuai dengan teori yang dibangun, bahwa untuk mengendalikan Free Cash Flow yang berlebihan oleh manajer, maka penggunaan Kebijakan Utang (DER) akan dipilih sebagai sumber pendanaan perusahaan, sehingga dapat mengurangi konflik keagenan dan agency cost of Free Cash Flow (Natasia dan Wahidahwati, 2015).

\section{Pengaruh Ukuran Perusahaan terhadap Kebijakan Utang (DER)}

Berdasarkan pengujian hipotesis 4, menunjukkan bahwa variabel Ukuran Perusahaan berpengaruh positif dan signifikan terhadap Kebijkan Utang (DER). Hal ini menunjukkan, bahwa Ukuran Perusahaan akan mempengaruhi besar kecilnya Kebijakan Uang (DER). Hal ini sesuai dengan teori yang dibangun, bahwa besar kecilnya ukuran suatu perusahaan akan 
berpengaruh terhadap utang perusahaan, yang didasarkan pada kenyataan bahwa semakin besar ukuran suatu perusahaan, maka kecenderungan menggunakan modal juga semakin besar.

\section{PENUTUP}

Hasil penelitian ini menunjukkan terdapat beberapa faktor yang mempengaruhi Kebijakan Utang (DER) yaitu Current Ratio berpengaruh positif dan signifikan terhadap Kebijakan Utang (DER). Sedangkan Struktur Aktiva berpengaruh negatif dan tidak signifikan terhadap kebijakan utang. Sementara itu, Free Cash Flow dan Ukuran Perusahaan berpengaruh positif dan signifikan.

Keterbatasan penelitian ini adalah bahwa Current Ratio (CR), Struktur Aktiva, Free Cash Flow (FCF), Ukuran Perusahaan memiliki prediksi yang rendah terhadap Kebijakan Utang (DER). Hal ini dapat terjadi karena estimasi model dicoba diterapkan pada perusahaan jalan tol, oleh sebab itu untuk mengatasi keterbatasan ini, hendaknya penelitian mendatang menggunakan estimasi model penelitian ini untuk pemecahan permasalahan Kebijakan Utang (DER) pada perusahaan sektor manufaktur atau pada sektor pertambangan, sehingga diharapkan akan mendapatkan gambaran yang lebih luas dalam memprediksi Kebijakan Utang (DER).

Berdasarkan keterbatasan penelitian di atas, maka agenda penelitian mendatang yang diusulkan dalam penelitian ini adalah menambahkan variabel lain untuk memprediksi kebijakan utang, misalnya: pertumbuhan perusahaan (Suryani dan Khafid, 2015), kebijakan dividen (Marhamah, 2016), Return on Assets (Surya dan Rahayuningsih, 2012).

\section{DAFTAR PUSTAKA}

Bambang Riyanto. (2001). Dasar - Dasar Pembelanjaan Perusahaan (Ketujuh). Yogjakarta: BPFE.

Brealey, M., \& Marcus. (2006). Dasar - Dasar Manajemen Keuangan Perusahaan Jilid 2. Jakarta: Erlangga.

Brigham, E. F., \& Houston, J. F. (2011). Dasar - Dasar Manajemen Keuangan Buku 2 Edisi 11 (Kesebelas). Jakarta: Salemba Empat.

Deviani, M. Y., \& Sudjarni, L. K. (2018). Pengaruh Tingkat Pertumbuhan, Struktur Aktiva, Profitabilitas, dan Likuiditas terhadap Struktur Modal Perusahaan Pertambangan di BEI. $\begin{array}{lllll}\text { E-Jurnal Manajemen } & \text { Universitas }\end{array}$ https://doi.org/10.24843/ejmunud.2018.v7.i03.p04 
Fahmi, I. (2011). Analisis Laporan Keuangan. Bandung: Alfabeta.

Ferdinand, A. (2014). Metode Penelitian Manajemen. Semarang: Badan Penerbit Universitas Diponegoro.

Hanafi, M. (2004). Manajemen Keuangan. Yogjakarta: BPFE.

Hanafi, M., \& Halim, A. (2009). Analisis Laporan keuangan. Yogjakarta: YKPN.

Hardiningsih dan Oktaviani. (2012). Determinan Kebijakan Hutang (dalam Agency Theory dan Pecking Order Theory). Dinamika Akuntansi, Keuangan Dan Perbankan, 1(1), 1124.

Ifada dan Yunandriatna. (2017). Faktor-Faktor yang Berpengaruh terhadap Kebijakan Hutang Perusahaan. Jurnal Akuntansi Dan Auditing, 14.

Indahningrum dan Handayani. (2009). Pengaruh Kepemilikan Manajerial, Kepemilikan Institusional, Dividen, Pertumbuhan Perusahaan, Free Cash Flow dan Profitabilitas terhadap Kebijakan Hutang Perusahaan. Jurnal Bisnis Dan Akuntansi, 11(3), 189-207.

Narita, R. M. (2012). Analisis Kebijakan Hutang. Journal UNNES, 1(2), 1-6.

Natasia dan Wahidahwati. (2015). Faktor-Faktor yang Mempengaruhi Kebijakan Hutang Perusahaan yang Terdaftar di BEI. Jurnal Ilmu\&Riset Akuntansi, 4(12), 22.

Prathiwi, N. M. D. I., \& Yadnya, I. P. (2017). Pengaruh Free Cash Flow, Struktur Aset, Risiko Bisnis, dan Profitabilitas terhadap Kebijakan Hutang. E-Jurnal Manajemen Unud, 6(1), 60-86.

Riyanto, B. (2001). Dasar-Dasar Pembelanjaan Perusahaan (Ketujuh). Yogjakarta: BPFE.

Sabir, M., \& Malik, Q. A. (2012). Determinants of Capital Structure - A Study of Oil and Gas Sector of Pakistan. Interdisciplinary Journal of Contemporary Research in Business, 395-400.

Sari, D. N., \& Prasetiono. (2015). Analisis Faktor-Faktor yang Mempengaruhi Kebijakan Hutang (Studi pada Perusahaan Manufaktur yang Terdaftar di BEI Tahun 2009-2013). Diponegoro Journal of Accounting, Vol.2(2), 1-10.

Sujarweni et al. (2014). Faktor-Faktor yang Mempengaruhi Kebijakan Hutang (Studi Empiris pada Perusahaan Manufaktur yang Terdaftar di BEI Tahun 2009 - 2012). JBTI, V No 1 Feb(1), 42-56.

Surya dan Rahayuningsih. (2012). Faktor-Faktor yang Mempengaruhi Kebijakan Hutang Perusahaan Non Keuangan yang Terdaftar dalam Bursa Efek Indonesia. Jurnal Bisnis Dan Akuntansi, 14(3), 213-225.

Suryani dan Khafid. (2015). Pengaruh Free Cash Flow, Pertumbuhan Perusahaan, Kebijakan 
keunis Majalah IImiah - ISSN No 2302-9315 Vol. 7 No 2 Thn VII Juli 2019

Dividen dan Ukuran Perusahaan terhadap Kebijakan Hutang pada Perusahaan Manufaktur di Bursa Efek Indonesia Tahun 2013. Dinamika Akuntansi, Keuangan Dan Perbankan, 4(1), 20-28.

Trisnawati, I. (2016). Faktor-Faktor yang Mempengaruhi Kebijakan Hutang pada Perusahaan Non Keuangan yang Terdaftar di Bursa Efek Indonesia. Jurnal Bisnis Dan Akuntansi, 18(1), 33-42. https://doi.org/10.1109/TWC.2009.081315

www.idx.com

www.neraca.co.id 